STUDIA I MATERIAŁY

DOI: 10.18276/sip.2018.54/1-08

\author{
Krzysztof Dmytrów*
}

Uniwersytet Szczeciński

\title{
COMPARISON OF THE TMAL AND THE TOPSIS METHODS IN SELECTION OF LOCATIONS IN ORDER-PICKING
}

\begin{abstract}
There are two methods of storing products in a warehouse. First, there is a dedicated storage, for which each product can be stored in only one location and one location is dedicated for just one product. There is also a shared storage, in which each location can store any number of various products and each product can be stored in many, sometimes very distant locations. The advantage of the dedicated storage is that it is very simple to manage and the pickers can quite easily remember, where each product is stored. The disadvantage of such system is that the storing space is used much less efficiently. The shared storage uses the storage space much better, but causes that remembering, where each product is stored is impossible. Therefore, if a company utilises the shared storage system, it must use a specialised system of warehouse management. Such system must manage, where to place replenishment orders and from where products should be taken in order to complete the customers' orders. The article compares the two multiple-criteria decision making techniques that will be used in order to select locations: the Taxonomical Measure of Location's Attractiveness (TMAL), based on the Composite Measure of Development and the TOPSIS method. The results show that no method can be considered as better in general.
\end{abstract}

Keywords: warehouse management, order-picking, multiple-criteria decision making, Composite Measure of Development, TOPSIS

JEL Codes: C38, C44 


\section{Introduction}

Although there are many modern, automated parts-to-picker systems of warehouse management, such as carousels, A-frames or AS/RS (Automated Storage-and-Retrieval Systems) (Bartholdi, Hackman, 2014), still vast majority of companies utilise classical, picker-to-parts approach, where the picker walks through the warehouse and collects the orders. There are many routing methods that can be used (optimal, S-shape, midpoint, return, largest gap, combined) (Tarczyński, 2012), but it is a secondary problem. There are two general methods of storing goods in a warehouse (Gudehus, Kotzab, 2012, p. 478):

- dedicated storage,

- shared storage.

In dedicated storage, one location is dedicated to one product only and one product can be stored only in one location. In shared storage, certain location can store many various products and one product can be stored in many, often very distant locations. Both methods have their advantages and disadvantages. Main advantage of dedicated storage is its simplicity and main disadvantage - poor space utilisation. Main disadvantage of the shared storage is the dispersion of products in the warehouse and main advantage of this method - much better space utilisation. Amongst shared storage methods there are such methods as: chaotic storage, closest open location storage, full-turnover storage, class-based storage or family-grouping (De Koster, Le-Duc, Roodbergen, 2007, p. 10-14). Whatever storing method is used, when completing the order, the question arises - if a product is stored in several locations, which one should be selected for picking the product for the order. The criteria of locations selection can be various (distance from the I/O point, quantity of product in the given location, number of other products in close neighbourhood, or storage time). The decision maker may use one, some or all of them by creating the synthetic variable, in which particular criteria will have appropriate weights. In the research the author used the two methods of locations selection. Both of them rank locations in which every completed product is located and select these locations, which have the highest position in the ranking. The first method, named TMAL (after the Polish abbreviation of the Taxonomic Measure of Location's Attractiveness), is based on the classical Composite Measure of Development, created by Hellwig (1968), The second method is the TOPSIS method, created by Hwang and Yoon (1981). In both methods, each location (alternative) was characterised by means of three criteria: 
a) the distance from the start;

b) the degree of demand satisfaction;

c) the number of other picked products in the neighbourhood of the analysed location.

The goal of the article is comparison of selection of locations by means of two above-mentioned methods and its impact on the picker's route.

\section{Assumptions, notations and methods}

The selection of locations is performed for each product separately. When they are selected, the route for the picker is designated.

The two applied methods are the multiple-criteria decision makingtechniques. They involve calculation of one, synthetic measure out of the set of arbitrarily selected criteria. In both methods the criteria must be strictly quantitative, measured at least on the interval scale. The applied criteria are:

a) the distance from the I/O point $\left(x_{1}\right)$;

b) the degree of demand satisfaction $\left(x_{2}\right)$;

c) the number of other picked products in the neighbourhood of the analysed location $\left(x_{3}\right)$.

The first criterion is the shortest distance from the I/O point. It is worth noting that it is measured not in such units as metres, but one unit is a shelf width. The Manhattan distance was used. This criterion is loss-type (the lowest possible value is most desirable) - if we have a choice, we would select closer to the I/O point location in order to minimise the distance. This criterion is measured on the ratio scale.

The second criterion - the degree of demand satisfaction measures, in what degree the demand in specific order is satisfied from the stock quantity in given location. It is calculated by means of the following formula:

$$
x_{2}= \begin{cases}\frac{l}{z} & \text { for } \quad z>l \\ 1 & \text { for } \quad l \geq z\end{cases}
$$

where:

$l$ - number of units of picked product in given location, $z$-demand for completed product.

If the amount of the product in the order in given location $(l)$ exceeds the demand for this product $(z)$, then the demand is fully satisfied in this location. And it does not 
matter, how much $l$ is larger than $z$. It means that the demand is satisfied in $100 \%$. Variable $x_{2}$ takes values from the range $(0 ; 1)$. It is the profit-type criterion (the highest possible value - in this case 1 - is desired) - we would rather pick the whole demand from one location than go to more than one. It is measured on the ratio scale.

The third criterion - the number of other picked products in the neighbourhood of the analysed location measures, how many other products (other than this, for which the locations' ranking is made) is in the neighbourhood of analysed location. First of all, the neighbourhood can be understood differently. In the case of the article, the neighbourhood consists of locations that are placed on the aisle, on which analysed location is placed. Variable $x_{3}$ takes integer values greater or equal 0 . As in the case of $x_{2}$, it is also the profit-type criterion (the highest possible value is desired) - if we pick the product from the location that is placed near locations, where the other completed products are, we can pick them without the need of going to other aisles or even further parts of the warehouse. This criterion is also measured on the ratio scale.

\subsection{Calculation of the $T M A L$}

Before further calculations, in the first step the loss-type criteria must be changed into the profit-type ones. One of the possibility is to calculate their inverse values. In our case, it was done with the variable $x_{1}$.

The Taxonomic Measure of Location's Attractiveness (TMAL) as a whole is based on the Composite Measure of Development. The stages of its calculation are as follows (Nowak, 1990):

4. Criteria were normalised.

5. Maximum values of normalised criteria were found, creating so-called "perfect alternative".

6. Euclidean distances ${ }^{1}$ between normalised criteria in a given location and the corresponding values from the "perfect alternative" were calculated.

7. Criteria were weighted.

8. Weighted distance between each location and the "perfect alternative" were calculated.

9. The $T M A L$ values were calculated and ranked in the descending order.

1 It's worth noting that the distance calculated in the TMAL has nothing in common with the distance of a location from the start. 
10. The highest-ranked location(s) were selected. If the demand was satisfied in the highest-ranked location, then only one was selected. If not, the next highest-ranked was also selected and so on, until full demand satisfaction.

\subsection{Stages of the TOPSIS method}

1. Criteria were normalised and weighed.

2. Normalised criteria were multiplied by their weights.

3. The worst and the best alternatives were determined.

4. Euclidean distances between variables in each location and the worst and the best alternatives were calculated.

5. For each location, the similarities to the worst condition were calculated and ranked in the descending order.

6. The highest-ranked location(s) were selected. If the demand was satisfied in the highest-ranked location, then only one was selected. If not, the next highest-ranked was also selected and so on, until full demand satisfaction.

For both methods the criteria were normalised by using the same method min-max normalisation:

$$
u_{i j}=\frac{x_{i j}-\min _{i} x_{i j}}{\max _{i} x_{i j}-\min _{i} x_{i j}} .
$$

Obtained normalised variable always has the minimum value equal 0 and maximum - 1 . Of course, there are many other methods of normalisation. Each of them has its advantages and disadvantages. Other normalisation methods will be analysed in further research within this area.

During calculations it can happen that a criterion (it can happen with variables $x_{2}$ and $x_{3}$ ) has the same values in every location (for example in all locations, where a certain product is placed, the demand for it in analysed order is satisfied in 100\%). In such case, values of normalised criteria were assumed to be 0 (although formally they cannot be calculated).

At certain stages of both TMAL and TOPSIS calculations, there is a need of weighting criteria. System of weights is purely subjective, but weights must satisfy one condition - their sum must equal one (or the sum might be the number of criteria - in our case 3). In the article, seven combinations of weights were assumed. They are presented in table 1 . 
Table 1. Combinations of weights

\begin{tabular}{|l|c|c|c|}
\hline \multirow{2}{*}{ Combinations } & \multicolumn{3}{|c|}{ Criteria } \\
\cline { 2 - 4 } & $x_{1}$ & $x_{2}$ & $x_{3}$ \\
\hline C1 & 0.333 & 0.333 & 0.333 \\
\hline C2 & 0.5 & 0.25 & 0.25 \\
\hline C3 & 0.25 & 0.5 & 0.25 \\
\hline C4 & 0.25 & 0.25 & 0.5 \\
\hline C5 & 0.4 & 0.4 & 0.2 \\
\hline C6 & 0.4 & 0.2 & 0.4 \\
\hline C7 & 0.2 & 0.4 & 0.4 \\
\hline
\end{tabular}

Source: own elaboration.

In the first combination we assume that each criterion has the same impact on the level of the TMAL coefficient and on the TOPSIS measure. It can be used as the reference point for other combinations. Combinations $\mathrm{C} 2, \mathrm{C} 3$ and $\mathrm{C} 4$ assume that one criterion has twice as big impact than other ones, and combinations $\mathrm{C} 5, \mathrm{C} 6$ and $\mathrm{C} 7$ assume that two criteria have twice as big impact than the remaining one.

\section{Numerical example}

In order to present, how the TMAL and TOPSIS methods compare to each other, ten real orders were analysed. The company, for which the orders were analysed, is a Polish division of large company that produces and sells tools and working clothes. The company orders and sells about 20 thousand products. They are stored in the large warehouse that consists of five sectors: A, B, C/K, D/E and R. There are also locations described as 0P-0X-0X-00. They are the "floor locations", where loose boxes are. Sectors A, B and C/K are the low-level sectors, the $\mathrm{D} / \mathrm{E}$ is the highlevel sector and the sector $\mathrm{R}$ is the sector, where spare parts are stored. Products in the analysed orders were stored only in low-level sectors (A, B and $\mathrm{C} / \mathrm{K}$ ). Locations in the warehouse are described by eight symbols: 0X-XX-XX-X0. First two symbols describe the sector, third and fourth symbols are the row of storage blocks, fifth and sixth symbols describe the storage shelf number and the last two symbols the rack (from bottom to top). For example, 0A-14-01-20, means that it is a location in the sector $0 \mathrm{~A}$, in the fourteenth row of storage blocks, in the first storage shelf in this row and on the second rack (racks are numbered from the bottom - shelves with the number 1 are the lowermost and with the number 6 - the uppermost). Rows 
of storage blocks are numbered as follows: odd rows are numbered in the ascending order from the left and even rows - in the descending order from the left. Warehouse layout is presented on the figure 1 .

Figure 1. Warehouse layout

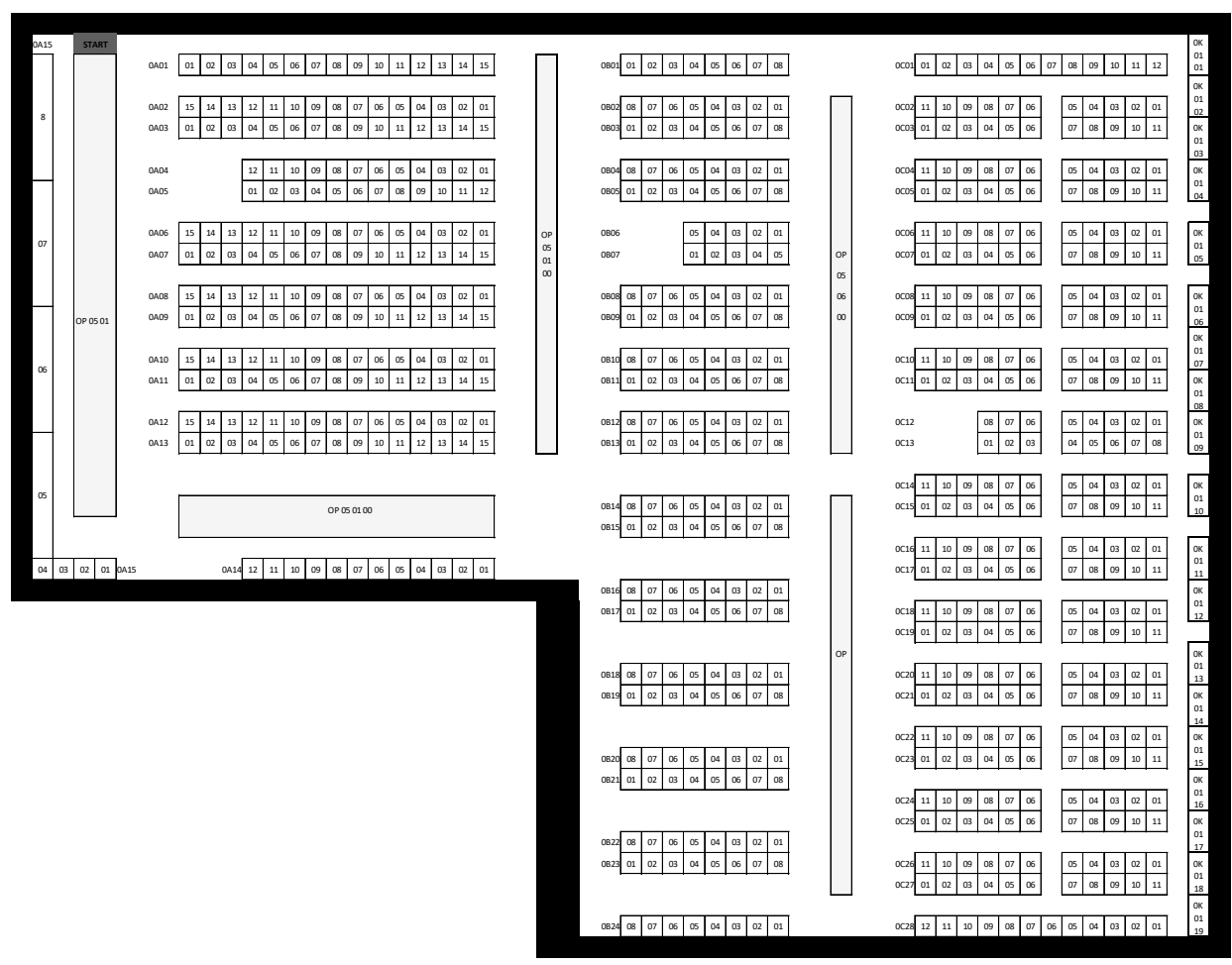

Source: own elaboration.

For every order, locations were selected by means of the TMAL and the TOPSIS methods for all seven combination of weights. Next, for every method and every combination of weights, the picker's route was designated. In every case, the s-shape method was used. The s-shape method is that the picker enters the first aisle, where the shelf with the picked product is. After picking all products in this aisle, he/she goes to the end of the aisle and goes to the next aisle, where the next products are. Then he/she picks them and goes to the beginning of the aisle and so on (Le-Duc, 2005, p. 22-23). The reason for using this particular method was that it was the most commonly used one in practice and it was also used in the analysed company. 
The shortest route, the better for the picker and for the whole system. The results of calculations are presented in the table 2 .

Table 2. Comparison of results generated by the TMAL and the TOPSIS methods

\begin{tabular}{|c|c|c|c|c|c|c|c|c|c|c|}
\hline \multicolumn{11}{|c|}{ TMAL } \\
\hline Combinations & O1 & $\mathrm{O} 2$ & $\mathrm{O} 3$ & $\mathrm{O} 4$ & O5 & O6 & $\mathrm{O} 7$ & O8 & O9 & $\mathrm{O} 10$ \\
\hline $\mathrm{C} 1$ & 199 & 226 & 274 & 118 & 326 & 288 & 228 & 224 & 235 & 273 \\
\hline $\mathrm{C} 2$ & 202 & 248 & 324 & 118 & 344 & 294 & 358 & 238 & 259 & 285 \\
\hline $\mathrm{C} 3$ & 205 & 226 & 274 & 118 & 292 & 274 & 256 & 224 & 234 & 265 \\
\hline $\mathrm{C} 4$ & 160 & 167 & 237 & 118 & 292 & 248 & 272 & 224 & 228 & 255 \\
\hline $\mathrm{C} 5$ & 205 & 281 & 297 & 118 & 332 & 342 & 309 & 224 & 240 & 265 \\
\hline C6 & 199 & 223 & 269 & 118 & 326 & 288 & 256 & 208 & 238 & 265 \\
\hline $\mathrm{C} 7$ & 167 & 167 & 256 & 118 & 292 & 274 & 272 & 184 & 230 & 255 \\
\hline \multicolumn{11}{|c|}{ TOPSIS } \\
\hline Combinations & $\mathrm{O} 1$ & $\mathrm{O} 2$ & $\mathrm{O} 3$ & $\mathrm{O} 4$ & O5 & O6 & O7 & O8 & O9 & $\mathrm{O} 10$ \\
\hline $\mathrm{Cl}$ & 202 & 220 & 287 & 118 & 322 & 292 & 198 & 236 & 245 & 275 \\
\hline $\mathrm{C} 2$ & 204 & 224 & 339 & 140 & 322 & 298 & 322 & 345 & 255 & 278 \\
\hline C3 & 178 & 215 & 280 & 118 & 294 & 285 & 278 & 239 & 245 & 260 \\
\hline $\mathrm{C} 4$ & 178 & 198 & 237 & 86 & 288 & 255 & 286 & 230 & 248 & 255 \\
\hline $\mathrm{C} 5$ & 204 & 282 & 312 & 104 & 322 & 324 & 295 & 230 & 265 & 264 \\
\hline C6 & 202 & 209 & 291 & 134 & 294 & 274 & 262 & 215 & 245 & 264 \\
\hline C7 & 178 & 209 & 256 & 86 & 295 & 265 & 268 & 195 & 232 & 248 \\
\hline
\end{tabular}

Source: owne laboration.

As seen in the table 2, generally the best results are obtained for combination $\mathrm{C} 4$ (in 7 out of 10 orders for the TMAL method and in 6 out of 10 orders for the TOPSIS method) - where criteria $x_{1}, x_{2}$ and $x_{3}$ have weights $0.25,0.25$ and 0.5 , respectively. It means that the most important feature is the number of other picked products in the neighbourhood of the analysed location. It means that selected locations may not be the closest to the start, the degree of demand satisfaction may not be the highest, but after selection the picker would have to visit locations that are relatively close to each other, so the route can be shorter. Quite good results were also obtained with the combination $\mathrm{C} 7$ (in 4 out of 10 orders for the TMAL method and in 5 out of 10 orders for the TOPSIS method- with weights $0.2,0.4$ and 0.4).

When comparing both methods of locations' selection for four analysed orders, the results were ambiguous. For 4 out of 10 orders, better results were obtained for the TMAL method, for other 4 ordersthe TOPSIS method was better and fore one order both methods generated the same the best solutions. More orders should be analysed in order to check, which method would give in general better results. 


\section{Conclusions}

The goal of the article was to present a comparison between selection of locations in the process of order-picking by means of the TMAL and the TOPSIS methods and its impact on the picker's route. The results showed that no method appeared to be better. However, in both methods the best combination of weights was the combination, in which the distance from the I/O point had weight 0.25 , the degree of demand satisfaction -0.25 , and the number of other picked products in the neighbourhood of the analysed location -0.5 . Quite good results were also obtained when the weights were $0.2 ; 0.4$ and 0.4 , respectively. The aim of the research was not generalisation of obtained results (there are too little orders analysed and the warehouse layout was too specific to generalise the results), but rather to present the possibilities to apply various methods of multiple-criteria decision making techniques in the locations' selection in order-picking.

Future research in this area would be to check other normalisation and ranking methods and also greater number of orders should be analysed. Then it would give the answer to the question, which method is the best one in this particular warehouse.

Of course, this method can be applied in other warehouses, also for high-level ones. Both TMAL and TOPSIS methods are quite versatile and we can add new criteria in order to adjust them to new conditions. It can also be included in packages that support warehouse management.

\section{References}

Bartholdi, J.J., Hackman, S.T. (2014). Warehouse \& Distribution Science, Release 0.96. The Supply Chain and Logistics Institute, School of Industrial and Systems Engineering, Georgia Institute of Technology, Atlanta, GA 30332-0205 USA.

De Koster, R., Le-Duc, T., Roodbergen, K.J. (2007). Design and Control of Warehouse Order Picking: a Literature Review. European Journal of Operational Research, 182 (2), 481-501.

Gudehus, T., Kotzab, H. (2012). Comprehensive Logistics, Second Edition. Berlin, Heidelberg: Springer-Verlag. DOI: 10.1007/978-3-642-24367-7.

Hellwig, Z. (1968). Zastosowanie metody taksonomicznej do typologicznego podziału krajów ze względu na poziom rozwoju oraz zasoby i strukturę wykwalifikowanych kadr. Przeglad Statystyczny, 15 (4), 307-326 (in Polish).

Hwang, C.L., Yoon, K. (1981). Multiple Attribute Decision Making: Methods and Applications. New York: Springer-Verlag. 
Le-Duc, T. (2005). Design and Control of Efficient Order Picking Processes. Ph Dthesis, RSM Erasmus University.

Nowak, E. (1990). Metody taksonomiczne w klasyfikacji obiektów społeczno-gospodarczych. Warszawa: PWE (in Polish).

Tarczyński, G. (2012). Analysis of the Impact of Storage Parameters and the Size of Orders on the Choice of the Method for Routing Order Picking. Operations Research and Decisions, 22, 105-120.

\section{PORÓWNANIE METOD TMAL I TOPSIS W WYBORZE LOKALIZACJI W PROCESIE KOMPLETACJI PRODUKTÓW}

\section{Streszczenie}

Istnieją dwie strategie przechowywania produktów w magazynie. Po pierwsze, można mówić o przechowywaniu dedykowanym, w którym każdy produkt jest przechowywany tylko w jednej lokalizacji, a każda lokalizacja jest przypisana tylko do jednego produktu. $\mathrm{Z}$ drugiej strony występuje przechowywanie współdzielone, w którym w każdej lokalizacji może być przechowywana dowolna liczba produktów i każdy produkt może być przechowywany w różnych, często bardzo od siebie oddalonych lokalizacjach. Zaletą przechowywania dedykowanego jest prostota w zarządzaniu i magazynierzy mogą łatwo zapamiętać, gdzie są przechowywane produkty. Jego wadą jest słabe wykorzystanie przestrzeni magazynowej. Przechowywanie współdzielone wykorzystuje przestrzeń magazynową znacznie lepiej, ale powoduje, że niemożliwe jest zapamiętanie, gdzie są przechowywane produkty. W związku z tym przy przechowywaniu dedykowanym ważne jest stosowanie systemu zarządzania magazynem. Taki system musi decydować, gdzie rozmieszczać produkty i skąd mają być pobrane, aby skompletować zamówienia od klientów. W artykule porównano dwie metody wielokryterialnego podejmowania decyzji, które będą zastosowane do wyboru lokalizacji: taksonomiczną miarę atrakcyjności lokalizacji (TMAL), opartą na syntetycznym mierniku rozwoju, oraz metodę TOPSIS. W wyniku przeprowadzonych badań stwierdzono, że żadna metoda nie dała jednoznacznie lepszych wyników

Słowa kluczowe: gospodarka magazynowa, kompletacja, wielokryterialne podejmowanie decyzji, syntetyczny miernik rozwoju, metoda TOPSIS 